\title{
Green synthesis of alkyl 8-(2-butyl-5-octyl-1, 3-dioxolan-4-yl)octanoate derivatives as potential biolubricants from used frying oil
}

\author{
Yehezkiel Steven Kurniawan, Kevin Thomas, Hendra, Jumina, Tutik Dwi Wahyuningsih* \\ Department of Chemistry, Faculty of Mathematics and Natural Sciences, Universitas Gadjah Mada, \\ Yogyakarta 55281 Indonesia
}

*Corresponding author, e-mail: tutikdw@ugm.ac.id

Received 10 Jan 2020

Accepted 12 Dec 2020

\begin{abstract}
Three pentanal-derived acetal esters have been prepared using a sonochemical method employing the principles of green chemistry. As many as two steps were required to produce these esters of alkyl 9,10dihydroxystearate in 67-85\% yield. The green synthesis evaluation was carried out through a comparison between reflux and sonochemical methods, as well as homogeneous and solid acid catalysts. Activation of Indonesian natural bentonite was conducted by Bronsted acid-enabled dealumination to obtain a low-cost solid acid catalyst. It was found that sonochemical esterification of the acid-catalyzed by H-bentonite gave products in up to $70 \%$ yield in 3 times shorter reaction time than the reflux method, which is remarkable. The final acetalization step with n-pentanal in the presence of H-bentonite with sonochemical method afforded three pentanal-derived dioxolane derivatives in 69-85\% yields, which are higher than the conventional method. Examination of the physicochemical properties of each product revealed that methyl 8-(2-butyl-5-octyl-1,3-dioxolan-4-yl)octanoate is the most suitable novel biolubricant to substitute currently commercial lubricant.
\end{abstract}

KEYWORDS: biolubricant, used frying oil, green synthesis, activated bentonite, sonochemical method

\section{INTRODUCTION}

As annual world energy consumption rises every year, the utilization of renewable raw materials as the energy source will undoubtedly play an important role in the near future [1-3]. Among available alternatives, vegetable oils are the most consumed materials $[4,5]$. Specifically, research concludes that vegetable oils have the potential to substitute currently used lubricant composed solely of hydrocarbons. This is because vegetable oils are abundantly available, biodegradable, and have low toxicity $[6,7]$. However, due to the unsaturation bonds are present, they exhibit low thermal and oxidative stability [8]. Structural modification of the vegetable oils is thus needed to overcome these problems, while at the same time maintaining their ability as biolubricant [9-12].

Efforts on biolubricant formulation from vegetable oils have been carried out to find the best biolubricant candidate [13-20]. Epoxidation of oleic acid and followed by a ring-opening reaction gave ether-based biolubricant; however, the biolubricant gave low viscosity index, which is unfavorable [13]. On the other hand, hydroxylation and acylation of oleic acid gave triester-based biolubricant; however, the total acid numbers were too high to be employed in a real application [14]. As part of our contribution to finding a substitute for conventional lubricant, we reported in our previous work that the ketal-derived ethyl 9,10-dihydroxystearate showed considerably good physicochemical properties, i.e. lower total acid number (TAN) value and iodine value (IV) than commercial lubricant $[15,16]$. Furthermore, the density of the esters is in the range of what is required to be a good lubricant. However, their total base number (TBN) value is still high $(14.0 \mathrm{mg} \mathrm{KOH} / \mathrm{g})$, which, in turn, indicates that further improvement is needed to obtain ideal biolubricant. Meanwhile, the aromatic aldehyde derivatives gave solid products, thus, the products could not be used as biolubricant [17].

On the other hand, green synthesis process of biolubricant has been also considered for a better future and environmental sustainability [21-24]. Anastas and Eghbali introduced the principles of green chemistry, some of which are the design of energy-efficient synthetic method, employ heterogeneous catalyst, conduction of less hazardous chemical syntheses, and use of safer chemicals and 
solvents [25]. One alternative to replacing reflux as a synthetic method is sonochemical synthesis as it utilizes sound waves rather than requiring heat for the reaction [26]. Heterogeneous catalysts are generally favored over homogenous catalysts in terms of a simple and green process [27].

Indonesia, specifically Tasikmalaya, is rich in natural clays. One of the most commonly found natural clays is bentonite. So far, bentonites have found variable uses such as acid catalyst [21], ionexchange agent [28], heavy metals adsorbent [29], and slow-release agent [30] in the industrial conversion of crude oil [31], owing to their porosity and acidity. Additionally, bentonite is able to act as a heterogeneous catalyst in esterification and then recovered after the reaction process [32]. To overcome all the aforementioned problems, in the present work, we reported the green synthesis of pentanal-derived dioxolane compounds and the evaluation of their potential application as biolubricants. Pentanal was selected because it is commercially available to be used as a raw material in the rubber and resin industries. The aspects of green chemistry met in this experiment were the use of the green synthesis method (sonochemistry), the avoidance of hazardous reagent (sulfuric acid), and the employment of heterogenous catalysis (activated bentonite). Furthermore, the physicochemical properties of the synthesized compounds were tested in comparison to the commercial lubricants.

\section{MATERIALS AND METHODS}

\section{Materials}

Used frying oil was obtained from a traditional market in Yogyakarta, Indonesia; while natural bentonite was obtained from Tasikmalaya, Indonesia. The other chemicals, such as sulfuric acid, methanol, ethanol, n-propanol, isopropanol, dichloromethane, pentanal, sodium hydroxide, potassium permanganate, anhydrous sodium sulfate, sodium bicarbonate, and $p$-toluenesulfonic acid ( $p$-TSA) were purchased from Merck in pro analytical grade and used without any further purification.

\section{Activation of natural bentonite}

Activation of natural bentonite was carried out through an acidic activation in a similar manner to the previously described procedure [33]. Briefly, natural bentonite $(250 \mathrm{~g})$ was grounded and filtered to 100 mesh. Then $1.0 \mathrm{M}$ sulfuric acid in distilled water was poured into the material and the mixture was heated at $350 \mathrm{~K}$ for $3 \mathrm{~h}$. The residue was filtered and washed with distilled water until the filtrate was free from sulfate ions. The residue was dried and filtered to 100 mesh to obtain activated bentonite (abbreviated as H-bentonite). Natural bentonite and H-bentonite were characterized by FTIR, XRD, surface analysis, and SEM-EDX.

\section{Esterification of used frying oil}

In the present work, used frying oil was utilized as the fatty acid source. Briefly, the mixture between used frying oil $(20 \mathrm{~g})$ and $20 \% \mathrm{wt} / \mathrm{vol}$ sodium hydroxide in methanol $(50 \mathrm{ml})$ was refluxed for $1 \mathrm{~h}$. Afterward, $n$-hexane $(3 \times 20 \mathrm{ml})$ was added into the mixture for extracting the fatty acid methyl esters as the product. The organic phase was dried over anhydrous sodium sulfate and, then, the solvent was removed under vacuum. The obtained fatty acid methyl esters were characterized by FT-IR (Fourier Transform Infrared, Shimadzu Prestige 21) and GCMS (Gas Chromatography-Mass Spectrometry, Shimadzu QP 2010S with Agilent GC Type 6890-MS Type 5973) spectrometry. See supplementary data for the characterization of the products.

\section{Hydrolysis of fatty acid methyl esters}

The mixture of fatty acid methyl esters (5.0 g) was added into $2 \% \mathrm{wt} / \mathrm{vol} \mathrm{KOH}$ in methanol $(30 \mathrm{ml})$; and the mixture was refluxed for $2 \mathrm{~h}$. After that, the mixture was acidified with $1 \mathrm{M}$ hydrochloric acid until a $\mathrm{pH}$ of 1.0 was reached. Then, petroleum ether $(5 \times 10 \mathrm{ml})$ was added to the mixture, the organic phase was dried over anhydrous sodium sulfate, and the solvent was removed under vacuum. The obtained fatty acids were characterized by FT-IR spectrometry.

\section{Esterification of 9,10-dihydroxyoctadecanoic acid}

The 9,10-dihydroxyoctadecanoic acid was prepared using potassium permanganate as the oxidation agent under an alkaline condition as previously described [16]. The 9,10-dihydroxyoctadecanoic acid $(0.316 \mathrm{~g}, 1 \mathrm{mmol})$ was dissolved in $100 \mathrm{mmol}$ of alcohol (methanol, ethanol, $n$-propanol, and isopropanol separately). Then acid catalyst ( $2 \mathrm{ml}$ of concentrated sulfuric acid or $50 \mathrm{mg}$ of heterogenous catalyst) was added to the mixture. The mixture was refluxed as a representative of the conventional method or sonicated for $10-30 \mathrm{~min}$. After the reaction had been completed, the catalyst was filtered off. Distilled water $(10 \mathrm{ml})$ was added to the filtrate. The precipitated product was filtered and 
recrystallized with acetonitrile to obtain the desired product.

\section{Acetalyzation of alkyl 9,10-dihydroxyoctadecanoate}

The alkyl 9,10-dihydroxyoctadecanoate ester ( $2 \mathrm{mmol})$ and $n$-pentanal $(0.2 \mathrm{~g}, 2 \mathrm{mmol})$ were dissolved in dichloromethane $(25 \mathrm{ml})$. Then, acid catalyst $(50 \mathrm{mg}$ of $p$-TSA or $50 \mathrm{mg}$ of heterogenous catalyst) was added to the mixture. The mixture was refluxed as a representative of the conventional method or sonicated for $30 \mathrm{~min}$. After the reaction, the mixture was filtered. Then, the organic phase was washed with brine $(10 \mathrm{ml})$ three times and $3.0 \% \mathrm{w} / \mathrm{t}$ sodium bicarbonate solution $(10 \mathrm{ml})$ twice. The organic phase was dried over anhydrous sodium sulfate and the solvent was removed under vacuum to obtain the desired product.

\section{Biolubricant test of alkyl 8-(2-butyl-5-octyl-1,3- dioxolan-4-yl)octanoates}

The density of the synthesized products was determined by a $10.0 \mathrm{ml}$ pycnometer according to the American Society for Testing and Material (ASTM) D1481 standard method. The dynamic viscosity and viscosity index of the synthesized products were measured by Ostwald viscometer according to ASTM D445 and D2770 methods.

The total acid number (TAN) of the synthesized products was determined by alkalimetric titration according to ASTM D964 standard method; while the total base number (TBN) of the synthesized products was determined by acidimetric titration according to ASTM D974 standard method. The iodine value (IV) of the synthesized products was determined by iodometric titration according to ASTM D2078 standard method. Each measurement was carried out in three replications and the average values from the measurement data were used.

\section{RESULTS AND DISCUSSION}

\section{Catalyst activation}

Characterization of H-bentonite using FT-IR spectroscopy (Fig. 1(A)) reveals that activation of bentonite has been successfully carried out. After the activation process, the $\mathrm{O}-\mathrm{Si}-\mathrm{O}$ stretching peak at $787 \mathrm{~cm}^{-1}$ is sharpened and the $\mathrm{TO}_{4}(\mathrm{~T}=\mathrm{Si}$ or Al) absorption peak becomes wider in the range of $1203-979 \mathrm{~cm}^{-1}$. These prove that the dealumination process by acid treatment of the parent natural bentonite is achieved since the $\mathrm{Si} / \mathrm{Al}$ ratio was decreased as previously described [29-31]. Further-

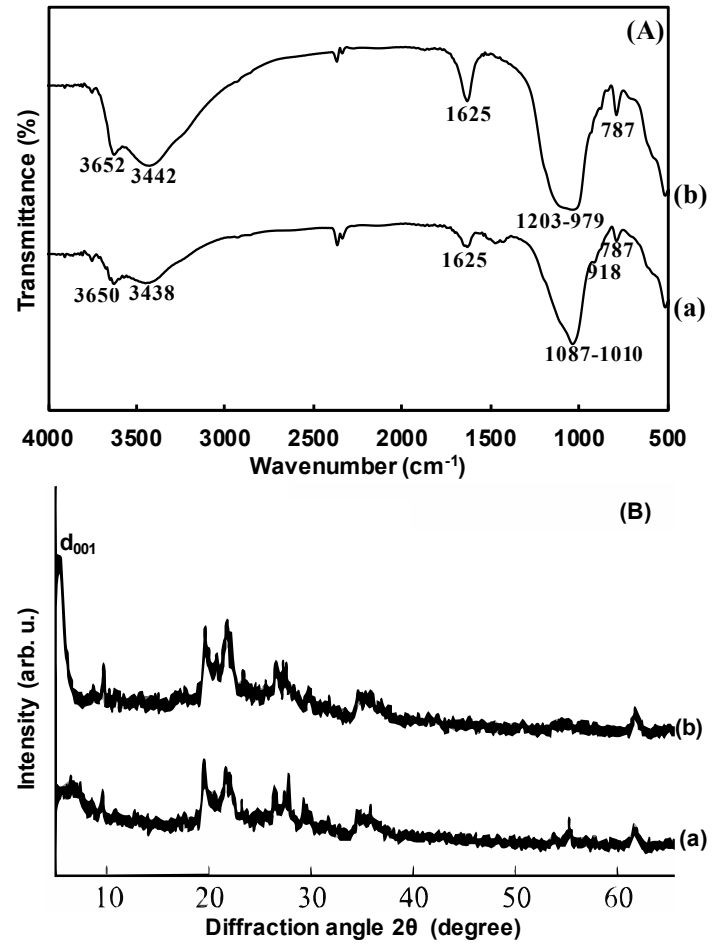

Fig. 1 (A) FTIR spectra and (B) XRD diffractogram of (a) bentonite and (b) H-bentonite.

more, the $\mathrm{O}-\mathrm{H}$ absorption peaks of silanol groups in $3400-3650 \mathrm{~cm}^{-1}$ were shifted towards larger wavenumbers as the cationic impurities coordinated to the water in the pore of zeolite is eluted during the activation process [29]. The success of bentonite activation can also be elucidated by the reduced $\mathrm{Al}-\mathrm{O}-\mathrm{Al}$ bending absorption intensity at $918 \mathrm{~cm}^{-1}$ as most of aluminum in the clay is dissolved in the acid. The XRD spectrum (Fig. 1(B)) shows that the $d_{001}$ peak of bentonite structure was shifted to a lower $2 \theta$ value (from 6.790 to 5.279 ) with a higher peak intensity confirming successful removal of impurities from bentonite structure; thus, the $\mathrm{d}_{001}$ was increased from 13.0076 to $16.7269 \mathrm{~nm}$. This result is in agreement with the previous literature [33]. The SEM images of both catalyst materials were shown in Fig. 2. After the activation process, the particles were well-distributed. Furthermore, from the gas adsorption isotherm analysis, the pore characters of natural bentonite and H-bentonite materials were listed in Table 1 . It was found that the surface area of the H-bentonite $\left(133.5 \mathrm{~m}^{2} / \mathrm{g}\right)$ is 1.7 times higher than that of the natural bentonite $\left(76.87 \mathrm{~m}^{2} / \mathrm{g}\right)$. Furthermore, the Bronsted acid sites were determined from the vapor adsorption of ammonia and pyridine on the surface 

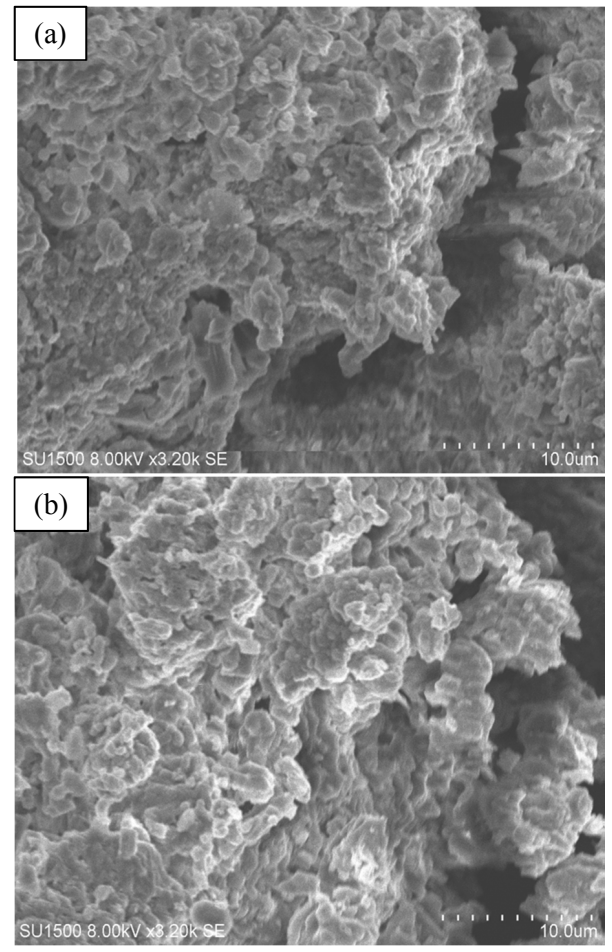

Fig. 2 SEM: (a) bentonite and (b) H-bentonite.

Table 1 Pore characters of natural bentonite and $\mathrm{H}$ bentonite materials.

\begin{tabular}{lccccc}
\hline Material & $\begin{array}{c}\text { Surface } \\
\text { area } \\
\left(\mathrm{m}^{2} / \mathrm{g}\right)\end{array}$ & $\begin{array}{c}\text { Pore } \\
\text { volume } \\
\left(\mathrm{cm}^{3} / \mathrm{g}\right)\end{array}$ & $\begin{array}{c}\text { Pore } \\
\text { size } \\
(\mathrm{nm})\end{array}$ & $\begin{array}{c}\text { Bronsted } \\
\text { acid site } \\
(\mathrm{mmol} / \mathrm{g})\end{array}$ & $\begin{array}{c}\text { Lewis } \\
\text { site } \\
(\mathrm{mmol} / \mathrm{g})\end{array}$ \\
\hline $\begin{array}{l}\text { Natural } \\
\text { bentonite }\end{array}$ & 76.87 & 17.7 & 8.40 & 2.89 & 3.29 \\
H-bentonite & 133.50 & 30.7 & 8.89 & 8.66 & 4.08 \\
\hline
\end{tabular}

of the catalyst material [34]. The Bronsted acid site on the H-bentonite is $8.66 \mathrm{mmol} / \mathrm{g}$, which is higher than that of the natural bentonite $(2.89 \mathrm{mmol} / \mathrm{g})$. Meanwhile, the Lewis acid site on the H-bentonite is $4.08 \mathrm{mmol} / \mathrm{g}$, which is higher than that of the natural bentonite $(3.29 \mathrm{mmol} / \mathrm{g})$. The increment of the Bronsted and Lewis acid sites would contribute to a higher catalytic activity of H-bentonite for the organic reaction [33]. The pore volume and pore size of the H-bentonite (Table 1) were also larger confirming that the activation process has been successfully carried out.

\section{Esterification of used frying oil and hydrolysis of fatty acid methyl esters}

The synthesis scheme of alkyl 8-(2-butyl-5-octyl1,3-dioxolan-4-yl)octanoate derivatives from used frying oil is shown in Fig. 3. The successful ester-
Table 2 Catalysis and method variation of the ester of alkyl 9,10-dihydroxystearate synthesis.

\begin{tabular}{lcccc}
\hline & & & \\
\hline
\end{tabular}

ification reaction of used frying oil was shown from the appearance of $\mathrm{C}=\mathrm{O}$ and $\mathrm{C}-\mathrm{O}$ ester bonds at 1743 and $1180 \mathrm{~cm}^{-1}$, respectively. These functional groups are characteristics for the production of fatty acid methyl ester $[17,18]$. From the GC-MS analysis through methylation of fatty acids, it was found that the used frying oil contains $1.20 \%$ myristic acid, $36.99 \%$ palmitic acid, $12.03 \%$ linoleic acid, $41.73 \%$ oleic acid, and $5.73 \%$ stearic acid. Meanwhile, the accomplishment hydrolysis reaction of the fatty acid methyl esters was shown from the shifting of $\mathrm{C}=\mathrm{O}$ signal from 1743 to $1712 \mathrm{~cm}^{-1}$ together with the appearance of $\mathrm{O}-\mathrm{H}$ signal at $3394 \mathrm{~cm}^{-1}$. These spectral changes are characteristics for the production of free fatty acid [17]. Afterward, the fatty acids were oxidized using potassium permanganate under alkaline conditions. From the mixture of fatty acids, only oleic acid could be reacted to form 9,10-dihydroxystearic acid; while the other fatty acids were eliminated through a recrystallization process [18]. The 9,10-dihydroxystearic acid was obtained in a $45.17 \%$ yield. 


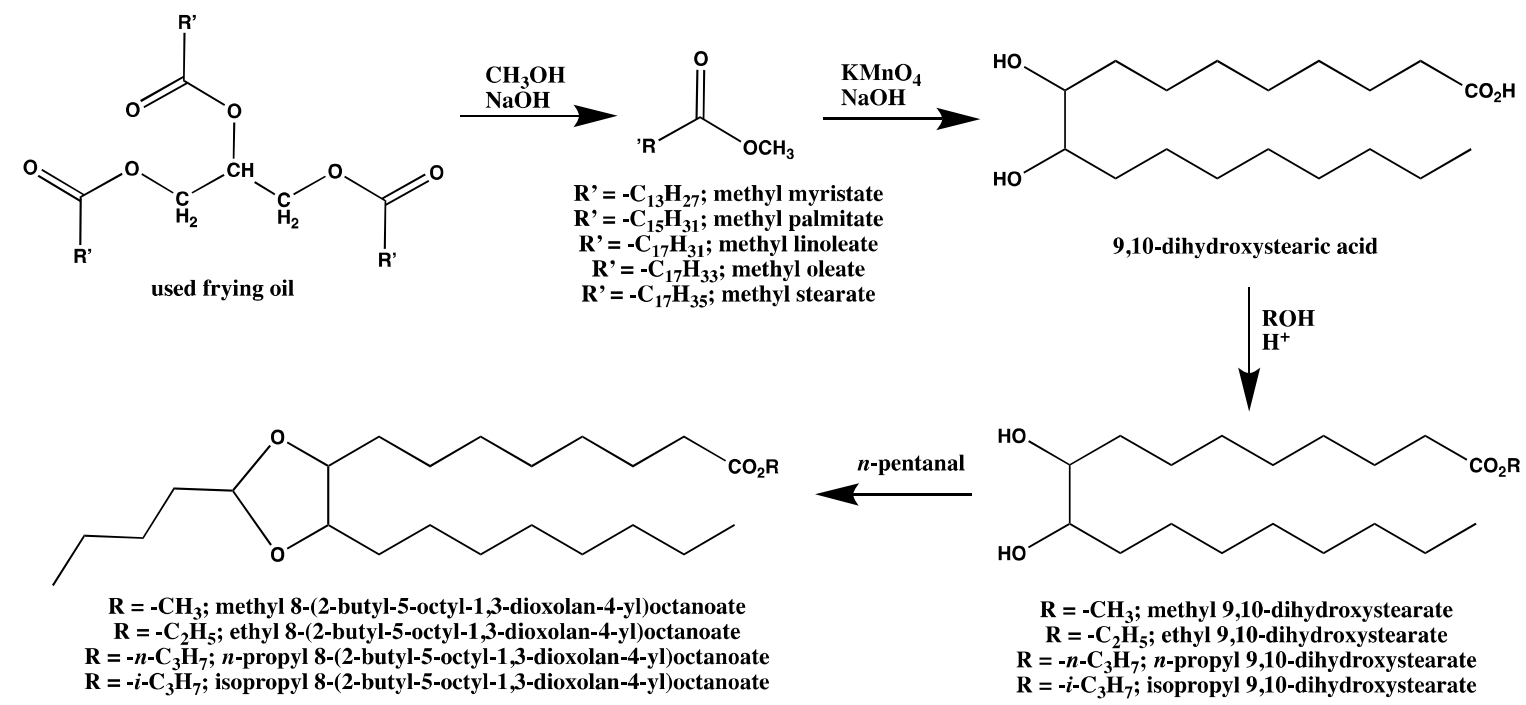

Fig. 3 Synthesis scheme of alkyl 8-(2-butyl-5-octyl-1,3-dioxolan-4-yl)octanoate derivatives from used frying oil.

\section{Green esterification of 9,10-dihydroxystearic acid}

The obtained 9,10-dihydroxystearic acid was esterified with various types of alcohol, i.e. methanol, ethanol, $n$-propanol, and isopropanol, in the presence of an acidic catalyst (concentrated sulfuric acid or natural bentonite or H-bentonite). The synthesis experiment was begun by comparing the esterification result between conventional, i.e. reflux (Table 2, entries 1, 5, 9, and 13), and sonochemical method (Table 2, entries 2, 6, 10, and 14). Both methods were conducted in the presence of concentrated sulfuric acid. The reflux method required a longer reaction time than the sonochemical method, and remarkable yield of each ester was obtained using the sonochemical method. However, much lower yield for sonochemical method was resulted, when ethanol, n-propanol, and isopropanol were used. It is reasonable since the reaction time of the reflux method was longer than the sonochemical method [26]. Despite this, the calculated energy needed to drive the sonochemical reaction $(257 \mathrm{~kW})$ was tremendously lower than the conventional method $(16000 \mathrm{~kW})$. Moreover, the time of reaction for sonochemical method (10 min) was three times shorter than the reflux one (30 min). Therefore, the product yield can be compensated by these facts.

With the decision that sonochemical method was reasonable to use, then, the synthesis process was moved on to analyze the performance of each heterogeneous catalyst on this sonochemical esterification reaction. Overall, under the same mass and reaction time, H-bentonite catalyzed the reaction more efficiently compared to natural bentonite (Table 2). This finding is in agreement with the reported literatures [31-33]. This higher catalytic activity of H-bentonite compared to natural bentonite is probably due to the higher number of acid site, larger surface area, larger pore volume, and larger pore size in H-bentonite (Table 1) so that 9,10-dihydroxystearic acid molecules are more efficiently bound to the active sites of the catalysts. Furthermore, the uniformity of H-bentonite aggregates is higher than its unmodified counterpart, as can be seen by the SEM image (Fig. 2). The yield of H-bentonite catalyzed esterifications are comparable to the conventionally obtained yield for methyl and ethyl esters using concentrated sulfuric acid. Thus, the protocol for green practical methyl and ester esterification of 9,10-dihydroxystearate was successfully established using a sonochemical method with H-bentonite catalyst, while the preparation of the propyl and isopropyl esters will remain a challenge in the future.

\section{Green synthesis of pentanal-derived dioxolanes}

Attempts to synthesize pentanal-derived dioxolanes were done by acetalization of methyl, ethyl, propyl, and isopropyl 9,10-dihydroxystearate. Firstly, we compared the acetalization product of methyl 9,10dihydroxystearate obtained between conventional (catalyzed by $p$-TSA) and greener method (catalyzed by natural bentonite or H-bentonite) to determine the better catalyst among the three of them (Table 3, entries 1-3). Unsurprisingly, the reaction 
Table 3 Effect of different catalysts on the yield of pentanal-derived dioxolanes.

\begin{tabular}{lcccc}
\hline Entry & $\mathrm{R}$ & Catalyst & $\begin{array}{c}\text { Reaction } \\
\text { time (min) }\end{array}$ & $\begin{array}{c}\text { Yield } \\
(\%)\end{array}$ \\
\hline 1 & $-\mathrm{CH}_{3}$ & $\begin{array}{c}\text { p-TSA } \\
\text { Bonication }\end{array}$ & 30 & 74 \\
2 & $-\mathrm{CH}_{3}$ & Bentonite & 30 & 68 \\
3 & $-\mathrm{CH}_{3}$ & H-bentonite & 30 & 85 \\
4 & $-\mathrm{CH}_{2} \mathrm{CH}_{3}$ & p-TSA & 30 & 67 \\
5 & $-\mathrm{CH}_{2} \mathrm{CH}_{3}$ & Bentonite & 30 & 59 \\
6 & $-\mathrm{CH}_{2} \mathrm{CH}_{3}$ & $\begin{array}{l}\text { H-bentonite } \\
\text { H-bentonite }\end{array}$ & 30 & 78 \\
7 & $-\mathrm{CH}_{2} \mathrm{CH}_{2} \mathrm{CH}_{3}$ & 30 & 69 \\
8 & $-\mathrm{CH}^{\left.-\mathrm{CH}_{3}\right)_{2}}$ & H-bentonite & 30 & 0 \\
\hline
\end{tabular}

catalyzed by H-bentonite gave the highest product yield compared to those catalyzed by p-TSA and natural bentonite. The same trend was observed for the synthesis using ethyl 9,10-dihydroxystearate as a substrate (Table 3, entries 4-6). This result indicated that the catalytic activity of H-bentonite as heterogeneous catalyst surpasses that of $p$-TSA as conventional homogeneous one, which fulfills the green chemistry principle [25]. One way to explain this finding is that $p$-TSA has a higher Bronsted acidic character than H-bentonite. Because acetalization is a reversible reaction, this ability of $p$-TSA has a major drawback as some of the $p$-TSA might hydrolyze the acetal back to the reactants. The calculated e-factor of using H-bentonite, i.e 3.91, is lower than using $p$-TSA, i.e 4.83. Lower e-factor describes that the procedure gives a lower amount of waste [25]. This is due to the fact that H-bentonite can be filtered out of the product mixture and further reused as a recycled catalyst. The parameter of yield and e-factor concluded that the sonochemical acetalization conducted in the presence of H-bentonite as catalyst was found as a greener method.

With this conclusion, propyl and isopropyl 9,10-dihydroxystearate were then subjected to the same sonochemical H-bentonite-catalyzed acetalization (Table 3, entries 7 and 8). The product obtained from $n$-propyl 9,10-dihydroxystearate was in gel form, which was, therefore, not suitable to be applied as lubricant. Meanwhile, the acetal was hardly obtained from isopropyl 9,10dihydroxystrearate due to steric hindrance. Therefore, the biolubricant evaluation was conducted only for methyl, ethyl, and n-propyl pentanalderived dioxolane compounds.

\section{Physicochemical properties of pentanal-derived dioxolanes}

Based on ASTM as the standard method [18], some physicochemical properties, such as density, viscosity, viscosity index, TAN, TBN, and IV, were determined for synthesized dioxolane compounds as grease and oleic acid as starting material. The results are presented in Table 4. A better lubricant has a low density to allow less mechanical work required by the machines [1]. Of all the products obtain, only methyl ester dioxolane has the density which is in the range of that required to be a good lubricant, i.e. $\quad 0.70-0.95 \mathrm{~g} / \mathrm{ml}$. Even though the methyl ester is denser than the commercial lubricant, both methyl and ethyl esters synthesized have a lower density than oleic acid. In these esters, only van der Waals forces present, while there are van der Waals and hydrogen bonding occurring intramolecularly in oleic acid [18]. The viscosities and viscosity indexes of methyl ester obtained are comparable to commercial lubricant. The high viscosity of lubricants is desired as it will prevent friction among metal parts in the machine [5].

The degree of engine corrosion due to the use of grease can be expressed as TAN [7]. As the acid functional group is converted into the corresponding esters, the resulting synthesized products have much a lower TAN value than oleic acid. The lower TAN value of methyl and ethyl esters means that the utilization of these compounds will result in lower probability of engine corrosion compared to that of commercial lubricants. On the other hand, TBN values can be used to interpret the ability of lubricants to neutralize the acids that might come from fuel combustion processes and prevent dirt from sticking on the engine component [1]. The higher value of TBN reveals the higher detergency ability of a compound. However, too high TBN value of a compound would make it not suitable as a lubricant, as the presence of base tends to hydrolyze ester back to the acids. From the result presented in Table 4, pentanal-derived dioxolane from methyl ester compensates both of these effects. In fact, its TBN is slightly higher than commercial lubricant but lower than our previously reported TBN for ketal derived dioxolane $(14.0 \mathrm{mg} \mathrm{KOH} / \mathrm{g})$. Lubricants are sometimes exposed to air and, consequently, those that have many double bonds or unsaturated groups could be oxidized [11]. The oxidative stability of a lubricant can be determined by a parameter called iodine value (IV). Dihydroxylation followed by acetalization of the alkene functional groups 
Table 4 Physicochemical properties of pentanal-derived dioxolanes.

\begin{tabular}{|c|c|c|c|c|c|c|}
\hline Compound & $\begin{array}{c}\text { Density } \\
(\mathrm{g} / \mathrm{ml})\end{array}$ & $\begin{array}{l}\text { Viscosity } \\
(\mathrm{mPa} \mathrm{s})^{\mathrm{a}}\end{array}$ & $\begin{array}{l}\text { Viscosity } \\
\text { index }\end{array}$ & $\begin{array}{c}\text { TAN } \\
(\mathrm{mg} \mathrm{KOH} / \mathrm{g})\end{array}$ & $\begin{array}{c}\text { TBN } \\
(\mathrm{mg} \mathrm{KOH} / \mathrm{g})\end{array}$ & $\begin{array}{c}\mathrm{IV} \\
\left(\mathrm{mg} \mathrm{I}_{2} / \mathrm{g}\right)\end{array}$ \\
\hline $\mathrm{R}=-\mathrm{CH}_{2}$ & 0.926 & 162 & 108 & 59.9 & 8.26 & 0.13 \\
\hline $\mathrm{R}=-\mathrm{CH}_{2}^{3} \mathrm{CH}_{3}$ & 0.977 & 59.8 & 105 & 38.2 & 16.8 & 0.58 \\
\hline $\mathrm{R}=-\mathrm{CH}_{2}^{2} \mathrm{CH}_{2}^{3} \mathrm{CH}_{3}$ & - & - & - & 18.1 & 27.5 & 0.84 \\
\hline Oleic acid 2 & 0.985 & 29.0 & 152 & 196 & 0.54 & 89.9 \\
\hline Commercial lubricant & 0.882 & 138 & 115 & 85.4 & 5.36 & 31.7 \\
\hline
\end{tabular}

${ }^{\text {a }}$ Dynamic viscosity at $313 \mathrm{~K}$.

yields $\mathrm{C}-\mathrm{O} \sigma$ bonds which are more stable than the $\pi$ bonds. This explains the lower IV of the ester products compared to oleic acid. Fortunately, these values are also lower compared to those in the commercial lubricant, with methyl esters having the best attribute as the potential biolubricant candidate for a real application.

\section{CONCLUSION}

The green synthesis of pentanal-derived alkyl ester dioxolanes has been performed in two-step sequence from 9,10-dihydroxystearic acid which is in turn obtained from used frying oil. Esterification of the acid by sonochemical method in the presence of H-bentonite gave alkyl 9,10-dihydroxystearates in reasonable yield and in a shorter reaction time than conventional method. Then, H-bentonitecatalyzed sonochemical acetalization of the esters with $n$-pentanal afforded methyl, ethyl, and $n$ propyl ester dioxolanes in higher yields than the obsolete method. Evaluation of phase, density, viscosity, TAN, TBN, and IV of each product reveals that methyl 8-(2-butyl-5-octyl-1,3-dioxolan-4yl)octanoate is the most suitable novel candidate as a biolubricant. These findings are hopefully expected to find application in the mechanical industry as means of contribution towards achieving environmentally benign processes.

\section{Appendix A. Supplementary data}

Supplementary data associated with this article can be found at http://dx.doi.org/10.2306/ scienceasia1513-1874.2021.010.

Acknowledgements: The authors thank the Ministry of Research Technology and Higher Education (Kemenristekdikti) of the Republic of Indonesia Indonesia for financial support.

\section{REFERENCES}

1. Reeves CJ, Siddaiah A, Menezes PL (2017) A review on the science and technology of natural and synthetic biolubricants. $J$ Bio Tribo Corros 3, 1-27.

2. Qian S-H, Hong L, Xu M, Cai Y-P, Lin Y, Gao J-S (2015) Cellulose synthesis in coloured cotton. ScienceAsia 41, 180-186.

3. Buasri A, Chaiyut N, Loryuenyong V, Rodklum C, Chaikwan T, Kumphan N, Jadee K, Klinklom P, et al (2012) Transesterification of waste frying oil for synthesizing biodiesel by KOH supported on coconut shell activated carbon in packed bed reactor. ScienceAsia 38, 283-288.

4. Soufi MD, Ghobadian B, Atashgaran M, Mousavi SM, Najafi G (2019) Biolubricant production from edible and novel indigenous vegetable oils: mainstream methodology and prospects and challenges in Iran. Biofuel Bioprod Bior 13, 838-849.

5. Singh Y, Sharma A, Singla A (2019) Non-edible vegetable oil-based feedstocks capable of bio-lubricant production for automotive sector applications - A review. Environ Sci Pollut Res 26, 14867-14882.

6. Salimon J, Salih N, Yousif E (2010) Biolubricants: Raw materials, chemical modifications and environmental benefits. Eur J Lipid Sci Technol 112, 519-530.

7. Carlsson AS (2009) Plant oils as feedstock alternatives to petroleum - A short survey of potential oil crop platforms. Biochimie 91, 665-670.

8. Jelani NAA, Azlan A, Ismail A, Khoo HE, Alinafiah SM (2017) Fatty acid profiles and antioxidant properties of dabai oil. ScienceAsia 43, 347-353.

9. Kananam W, Suksaroj TT, Suksaroj C (2011) Biochemical changes during oil palm (Elais guineensis) empty fruit bunches composting with decanter sludge and chicken manure. ScienceAsia 37, 17-23.

10. Phalakornkule $\mathrm{C}$, Mangmeemak J, Intrachod K, Nuntakumjorn B (2010) Pretreatment of palm oil mill effluent by electrocoagulation and coagulation. ScienceAsia 36, 142-149. 
11. Erhan SZ, Sharma BK, Peres JM (2006) Oxidation and low-temperature stability of vegetable oil-based lubricants. Ind Crops Prod 24, 292-299.

12. Talkit KM, Mahajan DT, Massand VH (2012) Physicochemical properties of soybean oil and their blends with vegetable oils for the evaluation of lubricant properties. J Chem Biol Phys Sci 3, 490-497.

13. Madankar CS, Dalai AK, Naik SN (2013) Green synthesis of biolubricant base stock from canola oil. Ind Crops Prod 44, 139-144.

14. Sammaiah A, Padmaja KV, Prasad RBN (2014) Synthesis and evaluation of novel acyl derivates from jatropha oil as potential lubricant base stocks. J Agric Food Chem 62, 4652-4660.

15. Wahyuningsih TD, Kurniawan YS, Amalia S, Wardhani TAK, Muriningsih CES (2019) Diethanolamide derivatives as a potential enhanced oil and used frying oil: Isolation, synthesis, and evaluation as nonionic biosurfactants. Rasayan J Chem 12, 741-748.

16. Kurniawan YS, Anwar M, Wahyuningsih TD (2017) New lubricant from used cooking oil: cyclic ketal of ethyl 9,10-dihydroxyoctadecanoate. Mater Sci Forum 901, 135-141.

17. Wahyuningsih TD, Kurniawan YS (2017) Green synthesis of some novel dioxolane compounds from Indonesian essential oils as potential biogrease. AIP Conf Proc 1823, ID 020081.

18. Kurniawan YS, Ramanda Y, Thomas K, Hendra, Wahyuningsih TD (2017) Synthesis of 1,4dioxaspiro[4.4] and 1,4-dioxaspiro[4.5] novel compounds from oleic acid as potential biolubricant. Indones $J$ Chem 17, 301-308.

19. Wahyuningsih TD, Kurniawan YS (2020) Synthesis of dioxo-dioxane and dioxo-dioxepane ethyl oleate derivatives as bio-lubricant base stocks. Indones $J$ Chem 20, 504-509.

20. Wahyuningsih TD, Kurniawan YS, Musphianti N, Ceristrisani N, Suryanti AD (2020) Evaluation of ethanolamide based nonionic biosurfactant materials from chemically modified castor oil and used palm oil waste. Indian J Chem Tech 27, 326-332.

21. Hossain MA, Iqbal MAM, Julkapli NM, Kong PS, Ching JJ, Lee HV (2018) Development of catalyst complexes for upgrading biomass into ester-based biolubricants for automotive applications: A review. RSC Adv 8, 5559-5577.

22. Owuna FJ, Dabai MU, Sokoto MA, Dangoggo SM, Bagudo BU, Birnin-Yauri UA, Hassan LG, Sada I, et al (2020) Chemical modification of vegetable oils for the production of biolubricants using trimethylolpropane: A review. Egyptian J Pet 29, 75-82.

23. Syahrullail S, Kamitani S, Shakirin A (2013) Performance of vegetable oil as lubricant in extreme pressure condition. Procedia Eng 68, 172-177.

24. Bande YM, Adam NM, Jamarei BO, Azmi Y, Razali SZ (2013) Examining the physicochemical properties and engine performance of biodiesel from whole seed and extracted kernels of egusi (Citrullus lanatus). ScienceAsia 39, 492-499.

25. Anastas P, Eghbali N (2010) Green chemistry: Principles and practice. Chem Soc Rev 39, 310-312.

26. Wood RJ, Lee J, Bussemaker J (2017) A parametric review of sonochemistry: Control and augmentation of sonochemical activity in aqueous solutions. Ultrason Sonochem 38, 351-370.

27. Zhao X, Wei L, Cheng S, Julson J (2017) Review of heterogeneous catalysts for catalytically upgrading vegetable oils into hydrocarbon biofuels. Catalysts 7 , ID 83.

28. Karnland O, Birgersson M, Hedström M (2011) Selectivity coefficient for $\mathrm{Ca} / \mathrm{Na}$ ion exchange in highly compacted bentonite. Phys Chem Earth 36, 1554-1558.

29. Liu X, Hicher P, Muresan B, Saiyouri N, Hicher P (2016) Heavy metal retention properties of kaolin and bentonite in a wide range of concentration and different pH conditions. Appl Clay Sci 119, 365-374.

30. He Y, Wu Z, Tu L, Han Y, Zhang G, Li C (2015 Encapsulation and characterization of slow-release microbial fertilizer from the composites of bentonite and alginate. Appl Clay Sci 109-110, 68-75.

31. Jiang Y, Li X, Qin Z, Ji H (2016) Preparation of $\mathrm{Ni}$ /bentonite catalyst and its applications in the catalytic hydrogenation of nitrobenzene to aniline. Chin $J$ Chem Eng 24, 1195-1200.

32. Moraes DS, Angélica RS, Costa CEF, Filho GNR, Zamian JR (2011) Applied clay science bentonite functionalized with propyl sulfonic acid groups used as catalyst in esterification reactions. Appl Clay Sci 51, 209-213.

33. Wijaya K, Ariyanti AD, Tahir I, Syoufian A, Rachmat A, Hasanudin (2018) Synthesis of $\mathrm{Cr} / \mathrm{Al}_{2} \mathrm{O}_{3}$ bentonite nanocomposite as the hydrocracking catalyst of castor oil. Nano Hybrid Compos 19, 46-54.

34. Utami M, Wijaya K, Trisunaryanti W (2018) Ptpromoted sulfated zirconia as catalyst for hydrocracking of LDPE plastic waste into liquid fuels. Mater Chem Phys 213, 548-555. 


\section{Appendix A. Supplementary data}

\section{CHARACTERIZATION OF THE SYNTHESIZED PRODUCTS BY FT-IR, GC-MS AND NMR}

\section{A: Isolation of oleic acid from used frying oil}

Reaction equation:

$$
\mathrm{RCOOH}(\mathrm{aq})+\mathrm{CH}_{3} \mathrm{OH}(\mathrm{l}) \longrightarrow \mathrm{RCOOCH}_{3}(\mathrm{aq})+\mathrm{H}_{2} \mathrm{O}(\mathrm{l})
$$

$17.27 \mathrm{~g}$ of fatty acid methyl ester was obtained with $85.92 \%$ reaction yield. FT-IR $\left(\mathrm{cm}^{-1}\right): 2924 \& 2835$ (C-H sp ${ }^{3}$ stretching), 1743 ( $\mathrm{C}=\mathrm{O}$ ester), $1458\left(\mathrm{CH}_{2}\right.$ bending), 1180 (C-O ester), 725 (cis $\mathrm{C}=\mathrm{C}$ ). GC-MS: $1.20 \%$ methyl myristate (retention time $\left(t_{R}\right)=23.7 \mathrm{~min}, \mathrm{M}^{+}=242$ ), $36.99 \%$ methyl palmitate $\left(\mathrm{t}_{\mathrm{R}}=\right.$ $\left.28.2 \mathrm{~min}, \mathrm{M}^{+}=270\right), 12.03 \%$ methyl linoleate $\left(\mathrm{t}_{\mathrm{R}}=31.6 \mathrm{~min}, \mathrm{M}^{+}=294\right)$, 41.73\% methyl oleate $\left(\mathrm{t}_{\mathrm{R}}=\right.$ $\left.31.8 \mathrm{~min}, \mathrm{M}^{+}=296\right)$, and $5.73 \%$ methyl stearate $\left(\mathrm{t}_{\mathrm{R}}=32.1 \mathrm{~min}, \mathrm{M}^{+}=298\right)$.

\section{B: Hydrolysis of fatty acid methyl esters}

Reaction equation:

$$
\mathrm{RCOOCH}_{3}(\mathrm{aq})+\mathrm{H}_{2} \mathrm{O}(\mathrm{l}) \longrightarrow \mathrm{RCOOH}(\mathrm{aq})+\mathrm{CH}_{3} \mathrm{OH}(\mathrm{aq})
$$

$3.77 \mathrm{~g}$ of fatty acids was obtained with $79.52 \%$ reaction yield. FT-IR $\left(\mathrm{cm}^{-1}\right): 3394(\mathrm{O}-\mathrm{H}$ stretching), 2924 \& $2854\left(\mathrm{C}-\mathrm{H}\right.$ sp ${ }^{3}$ stretching $), 1712\left(\mathrm{C}=\mathrm{O}\right.$ carboxylic acid), $1458\left(\mathrm{CH}_{2}\right.$ bending $), 1188(\mathrm{C}-\mathrm{O}$ carboxylic acid), 725 (cis $\mathrm{C}=\mathrm{C}$ ).

\section{C: Oxidation of oleic acid}

Reaction equation:

$$
\begin{aligned}
5 \mathrm{C}_{8} \mathrm{H}_{17} \mathrm{CH}=\mathrm{CHC}_{7} \mathrm{H}_{14} \mathrm{COOH}(\mathrm{l})+2 \mathrm{KMnO}_{4}(\mathrm{aq})+8 \mathrm{H}_{2} \mathrm{O}(\mathrm{aq}) & \\
& \longrightarrow 5 \mathrm{C}_{8} \mathrm{H}_{17} \mathrm{CH}(\mathrm{OH})-\mathrm{CH}(\mathrm{OH}) \mathrm{C}_{7} \mathrm{H}_{14} \mathrm{COOH}(\mathrm{aq})+2 \mathrm{Mn}(\mathrm{OH})_{2}(\mathrm{aq})+2 \mathrm{KOH}(\mathrm{aq})
\end{aligned}
$$

$1.47 \mathrm{~g}$ of 9,10-dihydroxystearic acid was obtained with $45.17 \%$ reaction yield. FT-IR $\left(\mathrm{cm}^{-1}\right): 3279-3202$ (O-H stretching), $2916 \& 2855$ ( $\mathrm{C}-\mathrm{H} \mathrm{sp}{ }^{3}$ stretching), 1697 ( $\mathrm{C}=\mathrm{O}$ carboxylic acid), $1435\left(\mathrm{CH}_{2}\right.$ bending).

\section{D: Esterification of 9,10-dihydroxyoctadecanoic acid}

Reaction equation:

$$
\mathrm{C}_{8} \mathrm{H}_{17} \mathrm{CH}(\mathrm{OH})-\mathrm{CH}(\mathrm{OH}) \mathrm{C}_{7} \mathrm{H}_{14} \mathrm{COOH}(\mathrm{aq})+\mathrm{ROH}(\mathrm{l}) \longrightarrow \mathrm{C}_{8} \mathrm{H}_{17} \mathrm{CH}(\mathrm{OH})-\mathrm{CH}(\mathrm{OH}) \mathrm{C}_{7} \mathrm{H}_{14} \mathrm{COOR}(\mathrm{aq})+\mathrm{H}_{2} \mathrm{O}(\mathrm{l})
$$

Methyl 9,10-dihydroxyoctadecanoate. White solid. m.p. 87.0-88.7 ${ }^{\circ} \mathrm{C}$. FT-IR $\left(\mathrm{KBr}, \mathrm{cm}^{-1}\right): 3271(\mathrm{O}-\mathrm{H}$ stretching), $2916 \& 2854$ ( $\mathrm{C}-\mathrm{H}$ sp ${ }^{3}$ stretching), 1735 ( $\mathrm{C}=\mathrm{O}$ ester stretching), $1443\left(-\mathrm{CH}_{2}-\right.$ bending), 1387 ( $-\mathrm{CH}_{3}$ bending), 1180 (C-O-C stretching). GC: a single peak at retention time $\left(\mathrm{t}_{\mathrm{R}}\right)=34.97 \mathrm{~min}$. ${ }^{1} \mathrm{H}-\mathrm{NMR}$ (500 MHz, $\mathrm{CDCl}_{3}$ ): $0.87\left(\mathrm{t}, 3 \mathrm{H},-\mathrm{CH}_{3}\right), 1.23-1.42\left(\mathrm{~m}, 24 \mathrm{H},-\mathrm{CH}_{2}-\right), 1.62\left(\mathrm{~m}, 2 \mathrm{H},-\mathrm{CH}_{2} \mathrm{CH}_{2} \mathrm{CO}-\right), 2.31$ (t, $2 \mathrm{H},-\mathrm{CH}_{2} \mathrm{CO}-$ ), 3.59 (m, $\left.2 \mathrm{H},-\mathrm{CH}-\mathrm{OH}\right), 4.11$ (s, $\left.3 \mathrm{H},-\mathrm{OCH}_{3}\right), 5.29$ (s, $\left.2 \mathrm{H}, \mathrm{OH}\right) . \mathrm{MS}: 312\left(\mathrm{M}^{+}-\mathrm{H}_{2} \mathrm{O}\right)$, 281, 187, 155, 139, 74 (Mc Lafferty rearrangement), 69, 55, 43 (base peak).

Ethyl 9,10-dihydroxyoctadecanoate. White solid. m.p. 82.0-83.0 ${ }^{\circ} \mathrm{C}$. FT-IR $\left(\mathrm{KBr}, \mathrm{cm}^{-1}\right): 3433(\mathrm{O}-\mathrm{H}$ stretching), $2924 \& 2854$ ( $\mathrm{C}-\mathrm{H} \mathrm{sp}^{3}$ stretching), 1735 ( $\mathrm{C}=\mathrm{O}$ ester stretching), $1465\left(-\mathrm{CH}_{2}-\right.$ bending), 1387 ( $-\mathrm{CH}_{3}$ bending), $1180\left(\mathrm{C}-\mathrm{O}-\mathrm{C}\right.$ stretching). GC: a single peak at retention time $\left(\mathrm{t}_{\mathrm{R}}\right)=34.88 \mathrm{~min}$. ${ }^{1} \mathrm{H}-\mathrm{NMR}$ $\left(500 \mathrm{MHz}, \mathrm{CDCl}_{3}\right): 0.87\left(\mathrm{t}, 3 \mathrm{H},-\mathrm{CH}_{3}\right), 1.27\left(\mathrm{t}, 3 \mathrm{H},-\mathrm{OCH}_{2} \mathrm{CH}_{3}\right), 1.23-1.42\left(\mathrm{~m}, 26 \mathrm{H},-\mathrm{CH}_{2}-\right)$, $1.62(\mathrm{~m}$, $2 \mathrm{H},-\mathrm{CH}_{2} \mathrm{CH}_{2} \mathrm{CO}-$ ), 2.29 (t, $2 \mathrm{H},-\mathrm{CH}_{2} \mathrm{CO}-$ ), 3.60 (m, $2 \mathrm{H},-\mathrm{CH}-\mathrm{OH}$ ), 4.11 (qt $2 \mathrm{H},-\mathrm{O}-\mathrm{CH}_{2} \mathrm{CH}_{3}$ ). MS: $342\left(\mathrm{M}^{+}\right), 313,281,155,88$ (Mc Lafferty rearrangement), 69, 55 (base peak), 43.

n-Propyl 9,10-dihydroxyoctadecanoate. White solid. m.p. 80.5-81.2 ${ }^{\circ} \mathrm{C}$. FT-IR $\left(\mathrm{KBr}, \mathrm{cm}^{-1}\right): 3279(\mathrm{O}-\mathrm{H}$ stretching), 2924 \& 2854 ( $\mathrm{C}-\mathrm{H}$ sp ${ }^{3}$ stretching), 1735 ( $\mathrm{C}=\mathrm{O}$ ester stretching), $1435\left(-\mathrm{CH}_{2}-\right.$ bending), 1387 ( $-\mathrm{CH}_{3}$ bending), $1180\left(\mathrm{C}-\mathrm{O}-\mathrm{C}\right.$ stretching). GC: a single peak at retention time $\left(\mathrm{t}_{\mathrm{R}}\right)=35.17 \mathrm{~min}$. ${ }^{1} \mathrm{H}-\mathrm{NMR}$ $\left(500 \mathrm{MHz}, \mathrm{CDCl}_{3}\right.$ ): 0.87 (t, 3H, $-\mathrm{CH}_{3}$ ), $0.93\left(\mathrm{t}, 3 \mathrm{H},-\mathrm{OCH}_{2} \mathrm{CH}_{2} \mathrm{CH}_{3}\right), 1.28-1.43\left(\mathrm{~m}, 24 \mathrm{H},-\mathrm{CH}_{2}-\right), 1.50$ (m, $2 \mathrm{H},-\mathrm{CH}_{2} \mathrm{CH}_{2} \mathrm{CO}-$ ), $1.63\left(\mathrm{~m}, 2 \mathrm{H},-\mathrm{OCH}_{2} \mathrm{CH}_{2} \mathrm{CH}_{3}\right), 2.29$ (t, $2 \mathrm{H},-\mathrm{CH}_{2} \mathrm{CO}-$ ), $3.59(\mathrm{t}, 2 \mathrm{H},-\mathrm{CH}-\mathrm{CH}-$ ), $4.02\left(\mathrm{t}, 2 \mathrm{H},-\mathrm{OCH}_{2} \mathrm{CH}_{2} \mathrm{CH}_{3}\right), 5.30(\mathrm{~s}, 2 \mathrm{H},-\mathrm{CH}-\mathrm{OH})$. MS: $281\left(\mathrm{M}^{+}-\mathrm{C}_{3} \mathrm{H}_{9} \mathrm{O}_{2}\right), 215,155,138,109,102$ (Mc Lafferty rearrangement), 83, 74, 69, 55, 43 (base peak). 
Isopropyl 9,10-dihydroxyoctadecanoate. White solid. m.p. 79.0-80.0 ${ }^{\circ} \mathrm{C}$. FT-IR $\left(\mathrm{KBr}, \mathrm{cm}^{-1}\right): 3395(\mathrm{O}-\mathrm{H}$ stretching), 2916 \& 2855 ( $\mathrm{C}-\mathrm{H}$ sp ${ }^{3}$ stretching), 1736 ( $\mathrm{C}=\mathrm{O}$ ester stretching), $1466\left(-\mathrm{CH}_{2}-\right.$ bending), 1387 $\left(-\mathrm{CH}_{3}\right.$ bending), 1180 (C-O-C ester stretching). GC: a single peak at retention time $\left(\mathrm{t}_{\mathrm{R}}\right)=36.92 \mathrm{~min}$. ${ }^{1} \mathrm{H}-\mathrm{NMR}\left(500 \mathrm{MHz}, \mathrm{CDCl}_{3}\right): 0.88\left(\mathrm{t}, 3 \mathrm{H},-\mathrm{CH}_{3}\right), 1.19\left(\mathrm{~d}, 6 \mathrm{H},-\mathrm{OCH}\left(\mathrm{CH}_{3}\right)\right), 1.28-1.43\left(\mathrm{~m}, 26 \mathrm{H},-\mathrm{CH}_{2}-\right)$, 2.32 (t, $\left.2 \mathrm{H},-\mathrm{CH}_{2} \mathrm{CO}-\right)$, 3.59 (t, $\left.2 \mathrm{H},-\mathrm{CH}-\mathrm{CH}-\right), 4.92\left(\mathrm{~m}, 1 \mathrm{H},-\mathrm{OCH}\left(\mathrm{CH}_{3}\right)\right), 5.31(\mathrm{~s}, 2 \mathrm{H},-\mathrm{CH}-\mathrm{OH})$. MS: $281\left(\mathrm{M}^{+}-\mathrm{C}_{3} \mathrm{H}_{9} \mathrm{O}_{2}\right), 215,186,155$ (base peak), 138, 109, 102 (Mc Lafferty rearrangement), 83, 74, $69,55,43$.

\section{E: Acetalyzation of alkyl 9,10-dihydroxyoctadecanoate}

Reaction equation:

$$
\begin{aligned}
\mathrm{C}_{8} \mathrm{H}_{17} \mathrm{CH}(\mathrm{OH})-\mathrm{CH}(\mathrm{OH}) \mathrm{C}_{7} \mathrm{H}_{14} \mathrm{COOR}(\mathrm{aq})+\mathrm{C}_{4} \mathrm{H}_{9} \mathrm{CHO}(\mathrm{l}) & \\
& \longrightarrow \mathrm{C}_{8} \mathrm{H}_{17} \mathrm{CH}\left(\mathrm{O}-\mathrm{CH}\left(\mathrm{C}_{4} \mathrm{H}_{9}\right)-\right)-\mathrm{CH}(\mathrm{O}-) \mathrm{C}_{7} \mathrm{H}_{14} \mathrm{COOR}(\mathrm{l})+\mathrm{H}_{2} \mathrm{O}(\mathrm{l})
\end{aligned}
$$

Methyl 8-(2-butyl-5-octyl-1,3-dioxolan-4-yl)octanoate. Yellowish liquid. FT-IR (KBr, $\left.\mathrm{cm}^{-1}\right)$ : 2916 \& 2855 ( $\mathrm{C}-\mathrm{H} \mathrm{sp}^{3}$ stretching), 1735 ( $\mathrm{C}=\mathrm{O}$ ester stretching), $1443\left(-\mathrm{CH}_{2}-\right.$ bending), $1387\left(-\mathrm{CH}_{3}\right.$ bending), 1180 (C-O-C ester stretching), 1072 (C-O-C ether). GC: a single peak at retention time $\left(\mathrm{t}_{\mathrm{R}}\right)=47.43 \mathrm{~min} .{ }^{1} \mathrm{H}-$ NMR (500 MHz, CDCl $)_{3}$ ): $0.88\left(\mathrm{t}, 6 \mathrm{H},-\mathrm{CH}_{3}\right), 1.20-1.48\left(\mathrm{~m}, 30 \mathrm{H},-\mathrm{CH}_{2}-\right), 1.61\left(\mathrm{~m}, 2 \mathrm{H},-\mathrm{CH}_{2} \mathrm{CH}_{2} \mathrm{CO}-\right)$, $2.31\left(\mathrm{t}, 2 \mathrm{H},-\mathrm{CH}_{2} \mathrm{CO}-\right), 3.60(\mathrm{t}, 1 \mathrm{H},-\mathrm{CH}-\mathrm{O}), 3.66\left(\mathrm{~s}, 3 \mathrm{H},-\mathrm{OCH}_{3}\right), 3.90(\mathrm{t}, 1 \mathrm{H},-\mathrm{CH}-\mathrm{O}), 4.87(\mathrm{t}, 1 \mathrm{H}$, $\left.n \mathrm{Bu}-\mathrm{CH}(\mathrm{O})_{2}\right) .{ }^{13} \mathrm{C}-\mathrm{NMR}\left(125 \mathrm{MHz}, \mathrm{CDCl}_{3}\right): 14.10,14.20,22.77,24.97,26.07,26.18,26.28,26.37,26.43$, $29.14,29.26,29.40,29.54,29.96,31.19,31.29,31.97,34.14,34.67,51.56\left(-\mathrm{OCH}_{3}\right), 78.58(-\mathrm{OCH}-)$, $79.67(-\mathrm{OCH}-), 103.60\left(n \mathrm{Bu}-\mathrm{HC}(\mathrm{O})_{2}-\right), 174.49(\mathrm{C}=\mathrm{O}) . \mathrm{MS}: 397\left(\mathrm{M}^{+}-\mathrm{H}\right), 341,281,263,155,139,97$, 83, 69, 55 (base peak), 43, 28.

Ethyl 8-(2-butyl-5-octyl-1,3-dioxolan-4-yl)octanoate. Yellowish liquid. FT-IR (KBr, $\left.\mathrm{cm}^{-1}\right): 2917$ \& 2854 ( $\mathrm{C}-\mathrm{H} \mathrm{sp}^{3}$ stretching), 1735 ( $\mathrm{C}=\mathrm{O}$ ester stretching), $1439\left(-\mathrm{CH}_{2}-\right.$ bending), $1386\left(-\mathrm{CH}_{3}\right.$ bending), 1180 (C-O-C ester stretching), 1073 (C-O-C ether). GC: a single peak at retention time $\left(\mathrm{t}_{\mathrm{R}}\right)=40.63$ min. ${ }^{1} \mathrm{H}-\mathrm{NMR}\left(500 \mathrm{MHz}, \mathrm{CDCl}_{3}\right): 0.88\left(\mathrm{t}, 6 \mathrm{H},-\mathrm{CH}_{3}\right), 1.03\left(\mathrm{t}, 3 \mathrm{H},-\mathrm{OCH}_{2} \mathrm{CH}_{3}\right), 1.26-1.43\left(\mathrm{~m}, 30 \mathrm{H},-\mathrm{CH}_{2}-\right)$, $1.51\left(\mathrm{~m}, 2 \mathrm{H},-\mathrm{CH}_{2} \mathrm{CH}_{2} \mathrm{CO}-\right.$ ), $2.31\left(\mathrm{t}, 2 \mathrm{H},-\mathrm{CH}_{2} \mathrm{CO}-\right.$ ), 3.65 (t, $\left.1 \mathrm{H},-\mathrm{CH}-\mathrm{O}\right), 3.78$ (t, $\left.1 \mathrm{H},-\mathrm{CH}-\mathrm{O}\right), 4.01$ (q, $2 \mathrm{H},-\mathrm{OCH}_{2} \mathrm{CH}_{3}$ ), 4.85 (t, $\left.1 \mathrm{H}, n \mathrm{Bu}-\mathrm{CH}(\mathrm{O})_{2}\right) .{ }^{13} \mathrm{C}-\mathrm{NMR}\left(125 \mathrm{MHz}, \mathrm{CDCl}_{3}\right.$ ): 14.14, 14.27, 14.96, 22.50, 24.88, 26.05, 26.51, 26.53, 26.66, 26.77, 29.06, 29.60, 29.72, 29.69, 29.97, 31.23, 31.74, 31.95, 34.42, 34.69, $61.63\left(-\mathrm{OCH}_{3}\right), 78.58(-\mathrm{OCH}-), 79.67(-\mathrm{OCH}-), 103.23\left(\mathrm{nBu}-\mathrm{HC}(\mathrm{O})_{2}-\right), 174.12(\mathrm{C}=\mathrm{O})$. MS: $412\left(\mathrm{M}^{+}-\mathrm{H}\right), 281,155,139,97,83,69,55$ (base peak), 43, 28.

n-Propyl 8-(2-butyl-5-octyl-1,3-dioxolan-4-yl)octanoate. White gel. FT-IR $\left(\mathrm{KBr}, \mathrm{cm}^{-1}\right): 2916$ \& 2855 ( $\mathrm{C}-\mathrm{H} \mathrm{sp}^{3}$ stretching), 1736 ( $\mathrm{C}=\mathrm{O}$ ester stretching), $1435\left(-\mathrm{CH}_{2}-\right.$ bending), $1387\left(-\mathrm{CH}_{3}\right.$ bending), 1180 (C-O-C ester stretching), 1072 (C-O-C ether). GC: a single peak at retention time $\left(\mathrm{t}_{\mathrm{R}}\right)=33.98 \mathrm{~min}$. ${ }^{1} \mathrm{H}-\mathrm{NMR}\left(500 \mathrm{MHz}, \mathrm{CDCl}_{3}\right): 0.87\left(\mathrm{t}, 6 \mathrm{H},-\mathrm{CH}_{3}\right), 0.93\left(\mathrm{t}, 3 \mathrm{H},-\mathrm{OCH}_{2} \mathrm{CH}_{2} \mathrm{CH}_{3}\right), 1.28-1.42(\mathrm{~m}, 30 \mathrm{H}$, $-\mathrm{CH}_{2}-$ ), 1.49 (m, 2H, $-\mathrm{CH}_{2} \mathrm{CH}_{2} \mathrm{CO}-$ ), $1.63\left(\mathrm{~m}, 2 \mathrm{H},-\mathrm{OCH}_{2} \mathrm{CH}_{2} \mathrm{CH}_{3}\right.$ ), 2.29 (t, 2H, $-\mathrm{CH}_{2} \mathrm{CO}-$ ), 3.58 (t, $1 \mathrm{H},-\mathrm{CH}-\mathrm{O}$ ), $3.88(\mathrm{t}, 1 \mathrm{H},-\mathrm{CH}-\mathrm{O}), 4.01\left(\mathrm{t}, 2 \mathrm{H},-\mathrm{OCH}_{2} \mathrm{CH}_{2} \mathrm{CH}_{3}\right.$ ), $4.86\left(\mathrm{t}, 1 \mathrm{H}, n \mathrm{Bu}-\mathrm{CH}(\mathrm{O})_{2}\right) .{ }^{13} \mathrm{C}-\mathrm{NMR}$ (125 MHz, $\mathrm{CDCl}_{3}$ ): 10.43, 14.03, 14.12, 22.07, 22.30, 22.70, 24.98, 26.04, 26.16, 26.21, 26.31, 26.36, 29.11, 29.20, 29.23, 29.63, 29.72, 29.78, 31.90, 34.29, 34.35, $65.89\left(\mathrm{EtCH}_{2}-\mathrm{O}-\right) 78.52$ (-OCH-), 78.60 (-OCH-), $103.53\left(\mathrm{nBu}-\mathrm{HC}(\mathrm{O})_{2}-\right), 174.07(\mathrm{C}=\mathrm{O}) . \mathrm{MS}: 425\left(\mathrm{M}^{+}-\mathrm{H}\right), 369,341,323,263,179,155,125$, 97, 83, 69, 57, 43 (base peak), 28.

Isopropyl 8-(2-butyl-5-octyl-1,3-dioxolan-4-yl)octanoate. The product was hardly obtained in less than $1 \%$ yield thus not characterized. 